\title{
Yerel Seçimlerde Seçmen Davranışını Etkileyen Faktörler: Muş Örneği*
}

\section{Factors Affecting Voter Behavior in Local Elections:Mus Sample}

\author{
Bayram Coşkun, ${ }^{a}$ Mehmet Şirin Çetin ${ }^{\text {b,** }}$ \\ Prof. Dr., Muğla Sıtkı Koçman Üniversitesi, İ̈BF, Kamu Yönetimi Bölümü, Muğla/Türkiye. \\ ORCID: 0000-0002-6803-7534 \\ Öğr. Grv., Muş Alparslan Üniversitesi, Malazgirt MYO, Muş/Türkiye. \\ ORCID:0000-0001-8181-744X
}

\section{MAKALE BİLGISI}

Makale Geçmişi:

Başvuru tarihi: 22 Ekim 2019

Düzeltme tarihi: 30 Kasım 2019

Kabul tarihi: 05 Aralık 2019

\section{Anahtar Kelimeler:}

Seçmen Davranışı

Yerel Siyaset

Muş

\section{A R T I C LE INFO}

Article history:

Received 22 October 2019

Received in revised form 30 November 2019

Accepted 05 December 2019

\section{Keywords:}

Voter Behavior

Local Politics

Muş
ÖZ

Seçmen davranışı ve seçmen davranışını etkileyen faktörler, farklı bilim alanlarının inceleme konusu yaptığı ve hakkında bilgi ürettiği bir alandır. Seçmen davranışını etkileyen faktörler genel ve yerel seçimler itibariyle farklılaşabilmektedir. Bu çalışmada önce seçmen davranışının kavramsal incelemesi, seçmen davranışı hakkında teorik yaklaşımlar ve seçmen davranışını etkileyen sosyolojik faktörler gibi konular literatür bilgisi doğrultusunda ele alınmıştır. Devamında Muş merkezde yerel seçimlerde seçmen davranışını etkileyen faktörleri belirleme amacıyla yürütülen bir alan araştırmasının bulgu ve sonuçları paylaşılacaktır. Alan araştırması Muş Belediyesi sınırları içinde yaşayan seçmenlere yönelik olarak yapılmış olup, ana kütleyi temsilen istatistiki olarak hesaplanan sayıda kișiye uygulanmıștır. Anket soruları, literatür bilgisi ve benzeri çalışmalarda kullanılan anket sorularından faydalanılarak bu araştırma kapsamında geliştirilmiştir. Verilerin analizi sonucunda seçmenlerin, yerel yönetimlerin öneminin farkında olduğu söylenebilir.

\section{A B S T R A C T}

Factors affecting voter behavior and voter behavior are a field in which different scientific fields make their research subject and produce information about it. The factors affecting to voters' behavior may differ in general and local elections. In this study, conceptual examination of voter behavior, theoretical approaches to voter behavior, and the sociological factors affecting voter behavior in the light of the literature were discussed. Besides, the findings and the results of a field survey conducted to determine the factors affecting voter behavior in the local elections in central of Mus will share. The field survey was conducted for the voters living in the borders of Mus Municipality and applied to the number of persons calculated as statistical representative of the population. Survey questionnaires developed within the scope of this research by making use of questionnaires with literature studies and similar studies used. As a result of the data analysis, it can be said that voters are aware of the importance of local governments.

\section{Giriş}

Yönetim insan için sosyal bir ihtiyaçtır. Ancak toplumu yönetenlerin nasıl belirlendiği/belirlenmesi gerektiği tarih boyunca tartışılan bir konu olmuştur. Modern devlet ile birlikte gelişen ancak kökenleri Eski Yunana dayanan demokrasi anlayışı ile birlikte yönetme yetkisinin halka ait olduğu genel kabul görmüştür. Ancak bu yetkinin doğrudan halk tarafından kullanılmasının birçok zorluk ve kısıtı olduğu için demokrasi türleri arasında temsili demokrasi ön plana çıkmıştır. Özellikle siyaset biliminin alanına giren kavramların (demokrasi, temsil, adalet, eşitlik, özgürlük, azınlık vb.) birçoğu, Gallie'nin “esasen tartışmalı” dediği kavramlar taifesindendir ve böyle oldukları için de

\footnotetext{
* Bu çalışmadaki alan araştırması Muş Alparslan Üniversitesi Sosyal Bilimler Enstitüsü Siyaset Bilimi ve Kamu Yönetimi Anabilim Dalında, Prof. Dr. Bayram Coşkun'un danışmanlığında yürütülen ve 2016 yılında tamamlanan yüksek lisan tez çalışması kapsamında yapılmıştır. Ayrıca çalışma, 1-3 Kasım 2018 tarihlerinde Alanya'da “Uluslar Arası Yerel Yönetimler Sempozyumu”nda sunulmuş bildirinin genişletilmiş ve gözden geçirilmiş halidir.

** Sorumlu yazar/Corresponding author

e-posta:ms.cetin@alparslan.edu.tr
} 
anlamları ve tanımları üzerinde bir mutabakat söz konusu değildir. Zaman zaman bir monark, diplomat, bayrak ve hatta seçilmiş bir yasama tarafindan karakterize edilebilen "temsil" de bu kavramlardandır. Ancak "esasen tartışmalı" bir kavram olmasından ötürü, kavramla ilgili tanımlarda doğal olarak büyük bir çeşitlilik göze çarpmaktadır(Bal, Bakan ve Koç, 2014: 130).

Temsili demokrasi uygulaması ile birlikte "seçim" vazgeçilmez bir nitelik kazanmıştır. Demokrasi tarihi, her dönem farklı araçlarla ve niteliklerle kendini göstermiş, günümüze gelinceye kadar bir terakki vitesi yaşamış olduğu söylenebilir. Antik dönemde demokrasi, Yunan şehir devletlerinde halkın doğrudan katılımıyla gerçekleşen klasik yöntem olarak ortaya çıkmıştır. $\mathrm{Bu}$ dönemde demokrasi; kadınların, yabancıların, kölelerin katılmadığı yalnızca halk olarak kabul edilen yirmi yaşını geçmiş, eli silah tutan yerli erkeklerin müdahil olduğu yönetimdir. Gelişen ve dönüşen toplumsal yapı olarak Feodal dönemde ise, daha önce feodal beyler ile kilise rahiplerinden oluşan kral meclislerine kentleri temsilen burjuvazinin dâhil edilmiş olması demokrasi sürecinin gelişmesinde önemli bir adım olmuştur. Bu dönemde Fransa ve İngiltere'de temsil kurumlarının varlığ 1 demokrasinin gelişiminde önem arz etmiştir. Nitekim İngiltere'de Kral meclisleri olan Witan ve Magnum Concillium'a burjuvazilerin katılmasiyla bu meclisler, günümüzdeki adıyla parlamento olarak dönüşmüştür. Benzer şekilde Fransa'da senyör ve rahiplerin yalnızca katıldığı Curia Regis'e burjuvazinin dâhil edilmesiyle Etats Generaux olarak dönüşmüştür. Sonrasında bu meclisler, giderek güçlenen burjuvazinin politik manevra alanı halini almıştır. Nihai olarak bu durum Fransız İhtilalı'nın habercisi olmuştur. Diğer bir ifadeyle, Batı'da 13. yüzyılda yaşanan siyasal, toplumsal, iktisadi gelişmeler öncelikle İngiltere ve Fransa'da ilk temsili kurumların (Parlamento, Etat Generaux) kurulmasina neden olmuştur. $\mathrm{Bu}$ ise gelecekte politik isteklerde bulanan burjuvazinin desteğiyle Fransız İhtilali gibi yeni bir dönemin önünü açmıştır (Koç, 2019:1114).

Modern devlet yapısı içinde yer alan yerel yönetimler açısından da seçim ve temsil meselesi oldukça önemli bir konu niteliğindedir. Çünkü doğası gereği yerel yönetimler, yerel halkı temsil eden kişiler tarafindan yönetilirler.

Seçim sürecinde bireyler/seçmenler birden çok seçenek içinden bir tercih yapma işlemini gerçekleştirmektedir. Böylece kendilerini temsil edecek kişileri belirleme yoluna giderler. Ancak seçim sürecinde seçmenlerin karar veya tercihlerini etkileyen faktörlerin ne olduğu konusu siyaset bilimi ve diğer birçok bilim alanı açısından merak ve araştırma konusu olmuştur. Böylece seçmen davranışı ve bu davranışlara etki eden faktörlerin incelenmesi bir bilimsel uğraş alanı haline gelmiştir. Seçmen davranışını etkileyen faktörler birden fazladır ve kesin sonuçlara varmak kolay olmasa da yapılan çalışmalarla kayda değer bulgular elde edilmektedir.

Konu ile ilgili literatür bilgisine göre seçmen davranışı genel ve yerel seçimler itibariyle değişebilmektedir. Seçmenler oyun kullanılması sürecinde tercihte bulunurken genel ve yerel seçimlerde farklı faktörlerden etkilenebilmektedir. Bunlar; sosyolojik, ekonomik ve sosyo-psikolojik faktörlerdir. Seçmen içinde bulunduğu duruma göre bu faktörlerden birinden ya da birkaçından aynı anda veya daha fazla etkilenerek tercihini oluşturmaktadır.

Burada ele alınan çalışma, Muş Merkez ilçede bulunan seçmenlerin yerel seçimlerde tercihlerini etkileyen faktörleri belirleme amacıyla yürütülmüştür. Ancak alan araştırmasının sonuçları ve bulgularının ortaya konulmasından önce konu ile ilgili temel teorik bilgiye değinilmede yarar görülmüştür.

\section{Genel Olarak Seçmen Davranışı ve Siyasal Katılma}

Genel olarak davranış, organizmanın belirli uyarıcılara karşı gösterdiği tepki olarak tanımlanabilir (Eroğlu, 2017:1) $\mathrm{Bu}$ tepki, iç ve dış etkilere karşı ortaya çıkar ve bilinçlidir. Bilinçli davranış esas itibariyle bir nedene dayalıdır ve mutlaka bir amacı vardır. Hareketten farklı olarak bilinçli davranış, davranışta bulunanın iradesi ve bireysel güdülerini yansıtır. ${ }^{1}$ Organizmadaki inançlar, tavırlar ve ihtiyaçlar bazı ön-yönelimler şeklinde ortaya çıkarak, algılanmış dürtülerle birlikte davranışa yol açar. Dürtüler ile organizma arasındaki ilişki algılama yolu ile sağlanmaktadır (Baykal, 1970:30). İnsan açısından davranışlar farklı amaçlara yönelik olabilirler, dolayısıyla birden çok davranış türünden bahsedilebilir. Davranış türlerinin bir örneği olan siyasal davranış ise, insanların siyasal olaylar karşısında takındıkları tavırlar, gösterdikleri eylem siyasal katılmalardır (Öztekin, 2010:459).

Birey olarak seçmenler, aynı derecede siyasete ilgi göstermezler. Bu davranışlarını etkileyen sosyo-ekonomik, psikolojik, kültürel ve çevresel çeşitli faktörlerden söz etmek gerekir. Gelir, eğitim, meslek, cinsiyet, yaş, köyde ya ,da kentte oturma, dinsel tercih ve etnik bir gruba mensubiyet gibi sosyoekonomik değişkenler siyasal katılma bakımından önemli değişkenler olarak karşımıza çıkmaktadırlar (Tokgöz, 2008:178). Büyük Türkçe Sözlükte siyasal katılma "bireylerin ve toplumsal kümelerin içinde yaşadıkları toplumsal çevrenin yönetimine, görev almak, seçmek, seçilmek, örgütlenmek, görüş açıklamak vb. yollarla katkıda bulunması" biçiminde açıklanmıştır.

Siyasal katılmanın tezahürü olarak seçmen davranışı topluluk üyelerinin yöneticilerini seçme işleminin yanı sıra, doğrudan veya dolaylı olarak kamu politikalarını etkileme amacıyla katıldıkları ortak işlevi de kapsar. Seçmen davranışı dışında, ulusal çapta ve ona eşdeğer başka bir siyasal davranış yoktur. Ancak seçimlerde "gizli oy" ilkesinin uygulanması araştırmacılar açısından verilen oy ile kişi arasında kesin bir bilgiye dayanan bir bağ kurulmasını imkânını ortadan kaldırmaktadır. Seçmen davranışına yönelik araştırmalarda ancak, toplu seçişler ve davranışlar incelenebilmektedir (Torlak ve Polat, 2006:73). Kışlalı'ya göre ise (1992:364), oyunu kullanmak için sandık başına giden seçmen, şu dört unsurdan biri veya birkaçını göz önüne alarak oyunu kullanmaktadır: "Güvenlik isteği”, "saygınlık isteği”, "duygusal bağlılık" ve “dinsel/siyasal inançlar”. Çok geniş bir kullanım alanı bulunan, "seçmen davranışı" insanın makro olarak dünyaya, mikro olarak da kişisel yaşamı ile alakalı meselelere, kuruluşlara, faal rol alanlara, toplumsal ve

\footnotetext{
1 Hasan Tutar, http://www.canaktan.org/yonetim/kurumsaldavranis/boyutlar.htm, e. t. 07.08.2018
} 
siyasi meselelere eğilmede yararlandığ 2008:2).

Sosyal çevresinde hak ettiği saygıyı görmediğine, ayrımcılığa maruz kaldığına inanan kimseler ise oy kullanırken, "güvenlik isteğii" talep eden seçmenlerin tersine, "değişim" yönünde oy tercihinde bulunur. Çünkü onların mevcut siyasal iktidardan bir memnuniyetsizliği bulunmakta ve belki de farklı bir siyasal partinin iktidarında ikinci sınıf insan muamelesi görmekten kurtulma şansları olduğunu düşünmektedirler (Kışlal1, 1992:364). Toplumcu seçmen tipinde ise seçmen davranışı şöyledir: Toplumcu seçmen, öncelikle toplumu düşünen ve siyasi yargıları sadece kendi durumlarına göre değil, ülkenin genel ekonomik durumuna göre değerlendiren seçmendir. Toplumcu seçmenler, ulusal ekonomilerin iyileşmesi durumunda iyiye giden ekonominin rantından bireysel olarak kendilerinin yararlanıp yararlanmadıklarına bakmaksızın iktidar partisine oy verirler (Altıntaş, 2010:12).

Kalaycıoğlu'na göre(2014: 4) seçmenin kararını etkileyen dolayısıyla seçmen davranışına etki eden olgular şunlardır:

- Seçmen küçük yaştan itibaren siyasal kişiliğini geliştirirken belirli bir siyasal partiye yakınlık duyar. Zamanla o partiyi tutmaya başlar ve tuttuğu partiye oy verir.

- Seçmenin belli bir siyasal görüşü, siyasete bakış açısı ve hatta siyasal ideolojisi vardır. Seçmen, o ideolojiyi temsil eden siyasal partiye oy verir.

- Seçmen, tıpkı tüketici gibi akli (ussal/rasyonel) karar alıcıdır. Geçmişte siyasal partilerin, özellikle hükümet parti (lerinin) ne yaptıklarına (performanslarına) bakar. Bunları değerlendirdikten sonra olumlu sonuç aldığı partiye oy verir.

- Seçmen tıpkı tüketiciler gibi akli karar alıcıdır. Geleceğe bakar, siyasal partiler içinde gelecekte kendisine, ailesine veya ülkesine yararlı olacağını düşündüğü partiye oy verir.

- Seçmen içinde bulunduğu toplumsal konuma, topluluğa, toplumsal sinifa göre siyasal partileri değerlendirir ve o toplumsal konuma yararlı gördüğü partiye oy verir.

Yerel yönetimlerin doğası gereği, bu kurumlar açısından siyasal katılım büyük öneme sahiptir. Çünkü yerel yönetimler yörede yaşayan insanları temsil eden kişiler tarafından yönetilirler. 1982 Anayasasının 127. maddesi yerel yönetimlerin karar organlarının seçimle işbaşına gelme ilkesini kabul etmiştir. 2000'li yıllarda gerçekleştirilen reformlar da yerel siyaseti güçlendirmiştir. $\mathrm{Bu}$ gelişmenin yerel kalkınma, demokratikleşme ve siyaset açısından oldukça olumlu yönleri yanında bazı muhtemel sorunlara da neden olabileceği değerlendirilmektedir (Çukurçayır, 2006:20).

\section{Seçmen Davranışı İle İlgili Teorik Yaklaşımlar}

Seçmen davranışına etki eden faktörlere yönelik üç temel teorik yaklaşım vardır. Bunlar; sosyolojik, sosyo-psikolojik ve ekonomik yaklaşımlardır (Akgün, 2002; Çalışır, 2017).

\subsection{Sosyolojik Yaklaşım}

Temeli Lazarsfeld, Berelson ve Gaudet tarafindan 1940 yılı ABD Başkanlık seçimleri sırasında seçmenler üzerinde yaptıkları bir araştırma ile atılan sosyolojik yaklaşım, seçmen davranışının temelinde toplumdaki sosyal gruplara ait olma duygusu ve eğilimleri olduğunu iddia eder. Seçimlerde kullanılan oy da aslında bireylerin ait olduğu sosyal kimliklerin siyasal tercihlere yansitılmasindan ibarettir Modelin temeli ferdin tutum ve tercihlerinin ilişkide olduğu insanlardan etkileneceği varsayımına dayanır (Akgün, 2002:65). Sosyolojik yaklaşımda daha çok din, sosyoekonomik statü, yaşanılan coğrafya parçası ve mensup olunan grup gibi faktörler ön plana çıkmaktadır (Çalışır, 2017:147).

\subsection{Sosyo-Psikolojik Yaklaşım}

$\mathrm{Bu}$ yaklaşım Seçmenlerin küçük yaşlarda ailelerinin ve çevrelerinin etkisi altında gerçekleşen siyasal sosyalleşme sürecinde kazandıkları siyasal tutumlar ve ideolojik yönelimlerin ileriki yaşlarda onların parti tercihi üzerinde son derece etkili olduğunu ve kişilerin herhangi bir partiye karşı ideolojik bağlılık duyduğu iddia eder (Akgün, 2002:29). Modelin özü, seçmenin bir partiye duyduğu sevgi ve bağlılı̆̆ ifade etmektedir. Bu bağlılık, bir taraftarın futbol takımı tutması gibi de değerlendirilmektedir. Bireyin partisiyle özdeşleşmesi için herhangi hukuki bir bağının bulunması da şart değildir (Özkan:2007:1-172'den aktaran; Çalışır, 2017:148).

\subsection{Ekonomik Yaklaşım (Rasyonel Tercih)}

Ekonomik tercih yaklaşımı, seçmenin kendi çıkarları doğrultusunda en iyi hizmeti verebilecek bir aday ve partiyi değerlendirerek buna göre oy verme eğiliminde olmasıdır. $\mathrm{Bu}$ yaklaşımda seçmenin amaç ve istekleri ön planda tutulmaktadır (Kalender, 2005:50-51'den aktaran; Çalışır, 2017:149). Ekonomik yaklaşıma göre seçmen, aday ya da partilerden kendisine en fazla yarar sağlayacağına inandığını tercih etmektedir (Doğan ve Göker, 2013:26-28).

\section{Alan Araştırmasının Sonuçları}

Muş merkez ilçede gerçekleştirilen alan araştırmasının genel sonuçlarını ele almadan önce, alanı tanıtma amaçlı bazı bilgilerin ifade edilmesinde yarar vardır. Aşağıdaki tablolarda alan araştırmasının yapıldığı tarihten önce gerçekleşen iki yerel seçimin sonuçları verilmiştir.

Tablo 1. 2009 Yerel Seçimleri Muş Belediye Başkanlığı Seçim Sonucu

\begin{tabular}{cccccccccccc}
\hline Parti & AKP & DTP & SP & MHP & CHP & DP & BTP & HYP & DSP & iP & BBP \\
\hline $\begin{array}{c}\text { Oy } \\
\text { Sayls! }\end{array}$ & 14.005 & 10.315 & 1.668 & 805 & 377 & $\begin{array}{c}14 \\
9\end{array}$ & 132 & 86 & 68 & 62 & 40 \\
\hline $\begin{array}{c}\text { Oy } \\
\text { Oranı }\end{array}$ & 50,50 & 37,20 & 6,00 & 2,90 & 1,40 & 0,5 & 0,50 & 0,30 & 0,20 & 0,20 & 0,10 \\
\hline
\end{tabular}

Kaynak: http://secim.haberler.com/2014/mus-secimsonuclari/

Tablo 1'de görüldüğü gibi, 2009 yerel seçimlerinde seçmen eğilimi ağırlıklı olarak sağ partilere oy verme biçiminde ortaya çıkmıştır. Kendini sağda konumlandıran siyasi partilerin toplam oy oranı \% 59.5'tir. Belediye başkanının seçiminde seçim sistemi olarak "çoğunluk sistemi" uygulandığından bu yerel seçimdeler Muş belediye 
başkanlığını AK Parti (Adalet ve Kalkınma Partisi) adayı kazanmıştır. Oy oranı açısından 2. sırada yer alan siyasi parti ise, DTP (Demokratik Toplum Partisi) olmuştur.

Tablo 2. 2014 Yerel Seçimleri Muş Belediye Başkanlığı Seçim Sonucu

\begin{tabular}{|c|c|c|c|c|c|c|c|c|c|}
\hline Parti & AKP & BDP & SP & MHP & HÜDAPAR & CHP & BTP & BBP & İP \\
\hline Oy Sayıs 1 & 18799 & 15812 & 1431 & 985 & 528 & 455 & 351 & 343 & 34 \\
\hline Oy Oranı & 48,5 & 40,8 & 3,7 & 2,5 & 1,4 & 1,2 & 0,9 & 0,9 & 0,1 \\
\hline
\end{tabular}

Kaynak: http://secim.haberler.com/2009/mus-secim-sonuclari/

Tablo 2'de görüldüğü gibi, 2014 yerel seçimlerinde siyasi yelpazenin sağında yer alan partilerin oy toplamında 2009 yerel seçimlerine kıyasla bir düşüş görülmektedir. Sağ partilerin bu seçimlerde aldığ 1 oy toplamı \% 55,6 olmuştur. AK Parti'nin bir önceki döneme göre oy oranını azalsa da yine de belediye başkanlığını bu partiye mensup olan aday kazanmıştır. Bu seçimde ikinci sırada oy alan parti ise BDP (Barış ve Demokrasi Partisi)'dir. BDP'nin DTP'nin devamı olduğu göz önünde bulundurulduğunda, bu siyasi yaklaşımın oy oranını arttırdığı görülmektedir.

\subsection{Alan Araştırmasının Yöntemi}

Alan araştırmasının evrenini Muş Belediyesi sınırları içinde yaşayan seçmenler oluşturmuştur. Örneklem sayısını/grubunu belirlemek için Muş İl Seçim Kurulu Başkanlığı'ndan belediye sınırları içinde yaşayan seçmen sayısı alınmış ve bu sayının 52.167 kişi olduğu tespit edilmiştir. Yapılan istatistiki hesaplama sonucunda ${ }^{2} \% 95$ güven düzeyi ve \% 5 hata payı ile 52.167 kişiden oluşan evrenden örneklem grubu olarak 380 kişi (seçmen) belirlenmiştir. Anket basit tesadüfi yöntemle uygulanmıştır. Anket uygulaması, ankete katılmak isteyen kişiler ile yüz yüze görüşme ile yapılmıştır. Ancak ankette siyasi görüş/değerlendirme içeren sorular olduğundan, ankete katılım teklifi sunulan kişiler içinde katılmama eğilimi oldukça yüksek olmuş bu da anketin uygulanmasını güçleştirmiştir.

Anket soruları, literatür bilgisinden ve yapılan benzeri çalışmalardan faydalanılarak çalışma kapsamında geliştirilmiştir. Anket formunda en başta katılımcıların cinsiyetleri, yaşları, gelir düzeyleri ve meslekleri gibi olgusal sorular ${ }^{3}$ yer almış, bunu takiben temel siyasi yönelime ilişkin bir soru yer almıştır. Devamda yer alan sorular, seçmenlerin yerel seçimdeki tercihlerini etkileyen faktörleri belirleme amacına yönelik olmuştur. Bu soruları takiben kentte yaşanılan sorunların katılımcılar açısından belirlenmesi amacına yönelik bir iki soru da anket kâğıdında yer almıştır. Toplamda anket kâğıdında olgusal sorular dâhil 20 soru yer almıştır. Anket soruları çoktan seçmeli seçenekle sahip olup, ayrıca ihtiyaç duyulan sorularda seçmenin farklı yorumları için serbest görüş bildirebilecekleri "diğer” seçeneği konulmuştur. Anketteki son soru açık uçlu olarak oluşturulmuştur.

Anketin değerlendirmesi SPSS programı aracılığıyla yapılmış olup, değerlendirme sırasında ihtiyaç duyulan istatistiki testler yapılmıştır. Bu kapsamda ihtiyaç duyulan

2 Örneklem sayısının belirlenmesi için literatürde belirtilen genel formüllerden yararlanılmıştır.

3 Olgusal soru türü için bkz. (Sencer, 1989:186-187). konularda sorular arasında çapraz ilişki kurularak, daha detaylı analiz yapma yoluna gidilmiştir.

\subsection{Alan Araştırmasına Katılan Kişilerin Genel Profili}

Anket formunda yer alan olgusal sorulara verilen cevaplar doğrultusunda katılımcıların belirlenen cinsiyeti, yaş, eğitim vb. konulardaki profili aşağıda yer alan tablolarda gösterilmiştir.

Tablo 3. Katılımcıların Cinsiyete Göre Dağılımı

\begin{tabular}{ccc}
\hline Cinsiyet & Sayı & $\begin{array}{c}\text { Yüzde } \\
(\%)\end{array}$ \\
\hline Kadın & 176 & 46,3 \\
\hline Erkek & 204 & 53,7 \\
\hline Toplam & 380 & 100,0 \\
\hline
\end{tabular}

Katılımcıların \% 46,3'ünü kadın seçmenler, \% 53,7'sini ise erkek seçmenler oluşturmuştur. Bu oranın Türkiye geneli seçmen profiline yakın bir oran olduğu söylenebilir. Dolayısıyla cinsiyet açısından araştıranın evrenine yakın bir dağılım elde edilmiştir. Anketin uygulaması sırasında kimi kadın seçmen araştırmaya çok ilgi göstermiş, kimi kadın seçmenin ise anket sorularını cevaplarken eşinin onayı alma ihtiyacını hissettiği gözlemlenmiştir. Anketin uygulanması sırasında ankete katılan erkeklerin de grup davranışından etkilendiği söylenebilir.

Tablo 4. Katılımcıların Yaş Gruplarına Göre Dağılımı

\begin{tabular}{ccc}
\hline Yaş & Sayı & Yüzde \\
\hline $18-25$ & 87 & 22,9 \\
\hline $26-35$ & 134 & 35,3 \\
\hline $36-45$ & 58 & 15,3 \\
\hline $46-55$ & 61 & 16,1 \\
\hline 56 ve üstü & 39 & 10,3 \\
\hline Cevapsız & 1 & 0,3 \\
\hline Toplam & 380 & 100 \\
\hline
\end{tabular}

Katılımcıların yaş grupları incelendiğinde \% 22,9'luk kısmın 18-25 yaş arası seçmenden oluştuğu görülmüştür. $\mathrm{Bu}$ seçmen grubunun büyük bir çoğunluğu ilk defa yerel seçimde oy kullanmış ve bu demokratik hakkını ilk defa tecrübe etmiş bir seçmen kitlesidir. 
Katılımcıların \% $35,3^{\prime}$ 'lük kısmını oluşturan 26-35 yaş grubu ise bize Türkiye geneli seçmen oranını doğru bir şekilde vermektedir. Türkiye geneli seçmen sayısı da bu yaş aralığında yoğunlaşmaktadır. Bu yaş grubu bir önceki yaş grubuna yakın ama aynı olmayan özellikler sergilemektedir. $\mathrm{Bu}$ grup bir önceki yaş grubuna göre daha zor risk alabilen ve daha sağlam adım atmayı tercih eden bir gruptur. 36-45 yaş grubunda olan \% 15,3'lük kısmı ise ve birkaç seçimi tecrübe etmiş, ülkenin daha zor günlerini görmüş ve bundan dolayı daha temkinli davranmayı tercih eden bir gruptur.

Katılımcıların \% 16,1'i 46-55 yaş arası olan bir önceki yaş grubuna yakın bir bakış açısına sahip bir kitleden oluşmaktadır. 56 yaş ve üstü seçmen oranı ise \% 10,3'lük bir kesimden oluşan en tecrübeli ve y1llar itibariyle yerel seçimleri ve belediye hizmetlerinin durumunu gözlemlemiş, dolayısıyla değerlendirme kapasitesi yüksek olan bir kitledir.

Tablo 5. Katılımcıların Öğrenim Durumuna Göre Dağılımı

\begin{tabular}{ccc}
\hline Eğitim Durumu & Sayı & Yüzde \\
\hline Okuryazar değil & 22 & 5,8 \\
\hline Okuryazar & 26 & 6,8 \\
\hline İlkokul mezunu & 37 & 9,7 \\
\hline Ortaokul mezunu & 26 & 6,8 \\
\hline Lise mezunu & 76 & 20,0 \\
\hline Ön lisans mezunu & 40 & 10,5 \\
\hline Lisans mezunu & 153 & 40,3 \\
\hline Toplam & $\mathbf{3 8 0}$ & $\mathbf{1 0 0 , 0}$ \\
\hline
\end{tabular}

Katılımcıların \% 5,8'i okuryazar değil, \% 6,8'i okuryazar, $\%$ 9,7'si ilkokul mezunu, \% 6,8'i ortaokul mezunu, \% 20,0'1 lise mezunu, \% 10,5'i ön lisans mezunu, \% 40,3'ü lisans mezunudur. Anketin uygulanması sırasında eğitim seviyesi ön lisans ve lisansüstü olan grupların, daha çok müzakere ve öneride bulunma şeklinde sorulara yaklaştıkları gözlemlenirken, eğitim seviyesi lise ve altı olan grupların ise daha çok seslerini duyurma şeklinde bir yaklaşım içinde oldukları gözlemlenmiştir.

Tablo 6. Katılımcıların Aylık Ortalama Gelirlerine Göre Dağılımı

\begin{tabular}{ccc}
\hline Aylık Gelir (TI) & Sayı & Yüzde \\
\hline 630,23 TL'den az & 66 & 17,4 \\
\hline 630,23 TL-1.674,58 TL & 68 & 17,9 \\
\hline 1.675 TL-2.407,22 TL & 78 & 20,5 \\
\hline $2.407,22$ TL-3.000 TL & 64 & 16,8 \\
\hline 3.000 TL ve üstü & 95 & 25,0 \\
\hline Cevapsiz & 9 & 2,4 \\
\hline Toplam & $\mathbf{3 8 0}$ & $\mathbf{1 0 0}$ \\
\hline
\end{tabular}

Kaynak: Yazarlar tarafından oluşturulmuş

Katılımcıların \% 17,4'ünün aylık ortalama 630,23 gelir seviyesi ile Türkiye Kamu-Sen'in Ağustos 2015 dönemine ait yaptığı ' Açlık ve Yoksulluk Sınırı', konulu araştırmaya göre açlık sınırının altında kalmıştır. Katılımcıların \% 17,9'u 630,23-1.674,58 TL'lik gelir ile dört kişilik bir ailenin gıda ve barınma harcamaları için gerekli olan gelire sahiptir. \% 20,5'i 1675-2.407,22 TL gelir elde eden k1sm1 oluşturmaktadır. Katılımcıların \% 16,8'lik kısmı 2.407,223.000 TL elde eden kesimden oluşurken, \% 25,0'1 3.000 TL ve üstü gelir elde etmektedir.

Gelir seviyesinin katılım ve seçmen tercihine etki ettiği ifade edilebilir. Gelir sahibi olan birey devletine karşı bazı sorumluluklarını yerine getirebilmekte (vergi vermek gibi) ve bundan dolayı hak talep etme hakkına sahip olduğunu düşünmektedir. Dolayısıyla belli bir gelir seviyesine ulaşmış ve temel ihtiyaçlarını karşılamış bir birey siyasal katılma hakkını doğru bir şekilde kullanabilmektedir. Gelir seviyesi düşük bireylerin tercihlerini sosyal yardım vb. olgular etkileyebilmektedir.

Tablo 7. Katılımcıların Son Yerel Seçimde (2014 yılında) Oy Kullanıp Kullanmadığ 1

\begin{tabular}{ccc}
\hline Seçenekler & Sayı & Yüzde \\
\hline Evet & 320 & 84,2 \\
\hline Hayır & 60 & 15,8 \\
\hline Toplam & $\mathbf{3 8 0}$ & $\mathbf{1 0 0 , 0}$ \\
\hline
\end{tabular}

Tablo 5'te görüldüğü gibi, katılımcıların \% 84,2'si 2014 yılındaki yerel seçimde oy kullandığını, \% 15,8'i ise oy kullanmadığını belirtmiştir. Katılımcıların bazısının yaşı küçük olduğundan, bazısının ise yaşı tutmasına rağmen, seçime katılmadığı için oy kullanamadığı düşünülmektedir. 2014 yerel seçimlerinde Muş'ta seçime katılım oranı \% 82,54'tür. Sonuç itibariyle katılımcıların büyük çoğunluğunun yerel seçimler konusunda tecrübe sahibi olduğu görülmektedir.

\subsection{Alan Araştırmasının Sonuçları}

Olgusal sorulardan sonra, sorulan sorulardan bir tanesi kişinin kendi dünya görüşünü/siyasi konumunu nasıl nitelendirdiğine ilişkin olup, devamı sorular yerel seçimde oy kullanma davranışına/tercihine etki eden faktörleri belirlemeye yöneliktir. Son bir iki soru ise, Muş'ta yerelde yaşanılan sorunların ne olduğunun seçmen gözüyle tespite yöneliktir. Anket formunda 6. sorudan itibaren tutum, kanı ve değerlendirme içeren sorulara ilişkin sonuçlar ve bu sonuçlara dayalı olarak yapılan değerlendirme ve analizler aşağıda yer almaktadır. 
Tablo 8. Katılımcıların Dünya Görüşü/Siyasi Düşünce Olarak Kendilerini Nasıl Tanımladığı

\begin{tabular}{ccc}
\hline Siyasi Görüsş & Sayı & Yüzde \\
\hline Milliyetçi & 44 & 11,6 \\
\hline Muhafazakâr & 80 & 21,1 \\
\hline Demokrat & 45 & 11,8 \\
\hline İslamcı & 46 & 12,1 \\
\hline Sosyal Demokrat & 50 & 13,2 \\
\hline Sosyalist-Marksist & 12 & 3,2 \\
\hline Fikir Beyan Etmek İstemiyorum & 80 & 21,1 \\
\hline Diğer & 16 & 4,2 \\
\hline Cevapsız & 7 & 1,8 \\
\hline Toplam & $\mathbf{3 8 0}$ & $\mathbf{1 0 0}$ \\
\hline
\end{tabular}

Tablo 6'da görüldüğü gibi, katılımcıların \% 21,1' bu soruya cevap vermekten kaçınmıştır. Aynı oranda katılımcı ise, kendini "muhafazakâr" olarak nitelendirmiştir. Günlük kullanımdaki muhafazakâr nitelendirmesinin dindarlığı da içerdiği bilinmektedir. Ankete katılanların \% 13,2'si ise sosyal demokrat olduğunu belirtmiştir. Bunun hemen devamında 4. Sırada kendini İslamcı olarak nitelendirilenler gelmektedir. Kendini demokrat ve milliyetçi olarak nitelendirenlerin oranı ise bir birine yakındır. Ancak küçük bir kent olmasına rağmen katılımcıların \% 3,2'inin kendini "Sosyalist-Marksist" olarak nitelendirmesi dikkat çekicidir. Bunların yanında katılımcıların yaklaşık dörtte biri temel siyasi yaklaşımını ifade etmemiştir. Bunun nedeni; seçenekler içinde kişilerin kendilerini ifade eden, bir seçeneğin olmaması olabileceği gibi, bazı seçmenleri siyasi görüşünü ifade etmek istememesi de olabilir. 2014 yılındaki yerel seçimde AK Parti ile BDP'de oy yığılması olduğu ve Tablo 6'daki sonuçlar birlikte dikkate alındığında, her iki partiye de oy veren seçmenin de tamamen homojen kitlelerden oluşmadığı söylenebilir. Dolayısıyla partiler arasında oy geçişkenliği farklı faktörlerin etkisiyle (aday vb.) mümkün görünmektedir.

Katılımcılara 7. Soru olarak "yerel seçimlerde oy vereceğiniz adayı/partiyi nasıl belirliyorsunuz?" sorusu sorulmuştur. $\mathrm{Bu}$ soru için altı farklı alternatif sunulmuş, ayrıca katılımcılara varsa farklı düşüncelerini belirtebilmeleri amaciyla cevaplar arasında "diğer" seçeneği de yer almıştır. Bu soruya verilen cevapların dağılımı aşağıdaki tabloda yer almaktadır.

Tablo 9. Katılımcıların Yerel Seçimlerde Oy Verecekleri Adayı/Partiyi Nasıl Belirledikleri

\begin{tabular}{ccc}
\hline Seçenekler & Sayı & Yüzde \\
\hline Önceki Yıllardaki Tecrübelerime Dayanarak Yaptığım Değerlendirme Sonucu & 195 & 31,76 \\
\hline Adayın/Partinin Çevre Konularına Yaklaşımını Göz Önüne Alarak & 88 & 14,33 \\
\hline Adayın/Partinin Altyapı Sorunlarına Yaklaşımını Göz Önüne Alarak & 76 & 12,38 \\
\hline Adayın/Partinin Sosyal ve Sportif Faaliyetlere Bakışııı Göz Önüne Alarak & 41 & 6,67 \\
\hline Sosyal Çevremle Yaptı̆̆ım Değerlendirme Sonucu & 80 & 13,02 \\
\hline Adayın/Partinin Vaatlerini Değerlendirerek & 86 & 14 \\
\hline Diğer & 48 & 7,82 \\
\hline
\end{tabular}

Not:Bu soruda katılımcılara birden fazla seçeneği işaretleme hakkı verilmiştir.

Tablo 9'a bakıldığında en büyük gurubun \% 31,6 ile önceki y1llarda edinilen tecrübeye dayılı olarak karar verdiğini belirten kişiler oluştuğu görülmektedir. Katılımcıların yaş dağılımına bakıldığında 26 yaş ve üstü olanların $\% 70,1$ oranına sahip olduğu görülmektedir. Aslında bu seçeneğin birinci çıkması, dolaylı olarak siyasi partiler açısından sadık bir seçmen grubu olduğuna da işaret etmektedir.

7. soruya cevap verenlerin 14,33'nün (ki bunlar en kalabalık ikinci grubu oluşturmaktadır) karar vermede adayların çevre konularına yaklaşımı esas aldığını belirtmesi ilginç bir durumdur. Muş’ta sınırlı bir sanayileşme olduğundan, halk tarafından gözlemlenen yaygın bir çevre sorunu yoktur. ${ }^{4}$ Buna rağmen

${ }^{4} \mathrm{Muşi} \mathrm{için} \mathrm{fiziksel} \mathrm{olarak} \mathrm{gözlemlenebilen} \mathrm{önemli} \mathrm{bir} \mathrm{çevre} \mathrm{sonunu}$ olarak, kentin kanalizasyonun boşaldığı Karasu nehrinin “adayın/partinin çevre konularına yaklaşımını göz önüne alarak" tercihte bulunduğunu belirtenlerin oransal olarak yüksek çıkması, seçmende belli bir çevre bilincinin oluştuğunu ifade etmektedir. Çevre sorunlarından sonra, seçmenin kentsel altyap1 konusunda da hassas olduğu anlaşılmaktadır. Bu kapsamda seçmenlerin \% 12,38'i "adayın/partinin altyapı sorunlarına yaklaşımını göz önüne alarak" tercini oluşturduğunu söylemiştir.

Tablo 7'daki sonuçlar, yerel seçimler sırasında adayların vaatlerinin de tercihte etkili olduğunu ortaya koymaktadır. Nitekim katılımcıların \% $\quad 14$ 'ü adayların/partilerin vaatlerine bakarak karar verdiğini belirmiştir. $\mathrm{Bu}$ durum

durumu belirtilebilir. Ancak bu da şehrin dişında olup, seçmenlerin günlük yaşam kalitesine doğrudan bir etkisi yoktur. 
seçmenlerin adayın hizmet etme kapasitesini de göz önünde bulundurduğunu açıkça ortaya koymaktadır. Katılımcıların $\%$ 12,82'si ise sosyal çevresi ile yaptığı değerlendirme sonucu karar verdiğini/tercihini oluşturduğunu belirmiştir. Muş’ta yerleşik olan insanlar arasında geleneksel ilişki türlerinin ( aşiret vb. ) hala geçerli olduğu bilinmektedir. Bu durum seçmenin bir kesimi için oy vermede aşiret bağları ile aile ilişkilerinin ağırlıklı faktörü oluşturduğunu göstermektedir. Sosyal ve sportif faaliyetlerin tercihlerin belirleyicisi olarak en düşük seviyede çıkması, temel kentsel hizmetlerin henüz tamamlanamamış olması ile açıklanabilir. Öyle anlaşıllyor ki, sosyal ve sportif faaliyetler, ikincil düzeyde ihtiyaç olarak algılanmaktadır.

Anketin 9. sorusu "belediye başkanlığı seçiminde nelere dikkat edersiniz" biçimde olmuş ve bu soru için katılımcılara birden fazla seçeneği işaretleme imkanı tanınmıştır. Bir önceki soru yerel seçim bağlamında sorulan genel nitelikli bir soru iken, bu soru doğrudan belediye başkanı seçimine ilişkin olup, konu somutlaştırılmıştır.

Tablo 10. Katılımcıların Belediye Başkanını Seçerken Nelere Dikkat Ettikleri

\begin{tabular}{|c|c|c|}
\hline Seçenekler & Sayı & Yüzde \\
\hline Adayın Kişiliğini Dikkate Alırım & 142 & 14,36 \\
\hline Adayın Dindar Olup Olmadığını Dikkate Alırım & 80 & 8,09 \\
\hline Adayın Etnik Kökenini Dikkate Alırım & 34 & 3,44 \\
\hline $\begin{array}{c}\text { Adayın Siyasi Deneyiminin Olup olmamasını } \\
\text { Dikkate Alırım }\end{array}$ & 95 & 9,61 \\
\hline Adayın Eğitim Durumunu Dikkate Alırım & 112 & 11,33 \\
\hline Adayın Fiziksel Görünümünü Dikkate Alırım & 9 & 0,91 \\
\hline $\begin{array}{l}\text { Adayın Hangi Partiye Mensup Olduğunu Dikkate } \\
\text { Alırım }\end{array}$ & 149 & 15,06 \\
\hline $\begin{array}{l}\text { Adayın Hangi Aşirete Mensup Olduğunu Dikkate } \\
\text { Alırım }\end{array}$ & 38 & 3,84 \\
\hline $\begin{array}{c}\text { Adayın Belediye Yönetimi Konusundaki Bilgi ve } \\
\text { Tecrübesini Dikkate Alırım }\end{array}$ & 189 & 19,11 \\
\hline $\begin{array}{c}\text { Adayın Yerel Ekonomiye Olumlu Katkı Yapıp } \\
\text { Yapmayacağını Dikkate Alırım }\end{array}$ & 135 & 13,65 \\
\hline Diğer & 6 & 0,60 \\
\hline
\end{tabular}

Not: Bu soruda katılımcılara birden fazla seçeneği işaretleme hakk1 verilmiştir.

Tablo 8'degörüldüğü gibi, katılımcıların \% 19,11'i belediye başkanını seçerken adayın belediye yönetimi konusundaki bilgi ve tecrübesini en önemli kriter olarak kullanmaktadır. Belediye başkanının seçiminde göz önünde tutulan ikinci en önemli faktör partidir. Partiye bağlı olarak tercihte bulunanların oranı da \% 15,06'dır. Üçüncü sırada adayın kişiliği gelmektedir. Katılımcıların \% 14,36'sı adayın kişiliğine bakarak tercihte bulunduğunu söylemiştir. ${ }^{5}$ Katılımcıların \% 13,65'i adayın yerel ekonomiye katk1 yapıp yapmayacağını gözeterek tercihte bulunacağını belirtmiştir. Bu da önemli bir olgudur ve yerel halkın, yerel yöneticilerden yerel ekonominin gelişimine katkıda bulunma biçiminde bir beklentisinin oluştuğunu göstermektedir. ${ }^{6}$

${ }^{5}$ Muğla İlinde yürütülen başka bir anket çalışmasında katılımcılara belediye başkanını seçerken göz önünde bulundurdukları özellikler sorulmuş, 1. sırada "adayın kişiliği" çıkmıştır. Adayın partisine bakarak karar verdiğini belirtenler 3. sırada yer almıştır (Coşkun ve Uzun, 1999:127).

${ }^{6} 593$ say1lı Belediye Kanunu 14. maddede belediyelerin görev ve sorumluluklarını belirtirken "ekonomi ve ticaretin
Bunların dıșında katılımcıların \% 11,32'si adayın eğitim durumunu, \% 9,60's1 siyasi deneyimini, \% 8,08'i dindar olup olmadığını, \% 3,84'i aşiretini, \% 3,43' etnik kökenini dikkate aldığını belirtmiştir. Bütün bu faktörler dikkate alındığında seçmenlerin yerel yöneticileri seçerken, oldukça bir birinden farklı faktörleri dikkate aldığı görülmektedir. Burada seçmenin \% 4'e yakının belediye başkanını seçerken aşiretine baktığını ifade etmesi de dikkat çekici bir konudur. $\mathrm{Bu}$ durum kent ortamında hala geleneksel ilişki türlerinin sürdürüldüğü göstermektedir. Ek tablo 1 'de 9. soru ile eğitim durumu arasında çapraz ilişki kurulmuştur. $\mathrm{Bu}$ tablo verilerine bakıldığında; okur-yazar olmayanlar içinde aşirete bakarak oy vereceğini söyleyenlerin oranı \% 45,45 iken, lisans mezunları arasında bu oran \% 4, 57'ye düşmektedir. Yine benzeri bir durum olarak, adayın "dindar olup almadığına bakarım" diyenlerin oranı okuryazar olmayanların arasında 31,81 iken, lisans mezunları için bu oran \% 17,64 'de düşmektedir. Bu durumun tersi bir sonuç "yerel ekonomiye katkı" konusunda ortaya çıkmaktadır. Bu seçenekte "adayın yerel ekonomiye katkısına bakarım" diyenlerin lisans mezunları arasında oranı \% 40,52 iken, okuryazar olmayanların için bu oran \% 18,18'e düşmektedir. Eğitim durumunun iki ucunda yer alan katılımcıların yaklaşımının kesiştiği özellikler de bulunmaktadır. Örneğin "adayın kişiliğini dikkate alırım" diyenlerin oranı okuryazar olamayanların arasında \% 45,45 iken, bu oran lisans mezunları arasında \% 42, 48'dir. Yine "adayın mensup olduğu siyasi partiyi dikkate alırım" diyenlerin oranı okuryazar olmayanların arasında \% 36,6 iken bu oran lisans mezunları için \% 40,52' dir.

Araştırmada 10. soru olarak "yerel seçimlerde oy kullanırken aşağıdaki faktörlerden hangisinden etkilenirsiniz" sorusu yöneltilmiş, soru için katılımcılara sunulan seçenekler ve bu seçenekler bağlamında verilen cevaplar Tablo 9'da sunulmuştur.

Tablo 11. Katılımcıların Yerel Seçimlerde Oy Kullanırken Hangi Faktörlerden Etkilendiği

\begin{tabular}{ccc}
\hline Seçenekler & Sayı & Yüzde \\
\hline Aile Büyüklerimin Etkisinde Kalırım & 51 & 11,86 \\
\hline $\begin{array}{c}\text { Gazete ve Televizyon Yayınları İle Sosyal Medyanın } \\
\text { Etkisinde Kalırım }\end{array}$ & 51 & 11,86 \\
\hline Çevremin (Arkadaş, Okul) Etkisinde Kalırım & 28 & 6,51 \\
\hline Kanaat Önderlerinin Etkisinde Kalırım & 22 & 5,12 \\
\hline Cemaat/Tarikat Büyüklerinin Etkisinde Kalırım & 19 & 4,42 \\
\hline Hiçbiri & 210 & 48,84 \\
\hline Diğer & 49 & 11,39 \\
\hline
\end{tabular}

Not: Bu soruda katılımcılara birden fazla seçeneği işaretleme hakkı verilmiştir.

Tablo 11'da görüldüğü gibi, yerel seçimlerde oy kullanırken katılımcıların \% 48,84'ü aile büyükleri, kanaat önderi, arkadaş çevresi gibi faktörlerin etkisinde kalmadığını belirtmiştir. Ancak katılımcıların yaklaşık \% 40 ' 1 ise çevresinin veya basının etkisine maruz kaldığını

geliştirilmesi” hizmetlerini de belediyerin görev alanına dahil etmiştir. Buna bakıldığında vatandaşın bu konudaki beklentisinin yasal bir temelinin olduğu da görülmektedir. 
ifade etmiştir. Bu etkilerin en önemlileri "aile büyükleri" $(\% 11,86)$ ile basın yayın kuruluşları ve sosyal medyadır $(\%$ 11,86). Aile büyüklerinin seçmen tercihinde etkide bulunması yine geleneksel ilişkilerin kent ortamında kimi ailelerce sürdürüldüğünün işaretidir. Medya ve sosyal medyadan da etkilenilmesi ise, moderrn iletişim araçlarına aşina olan ve bunları kullanan bir toplumsal kesime işaret etmektedir. Yerel seçimler birden fazla oy kullanılan seçim olması sebebiyle genel seçimlere göre bilgilenme ihtiyacı daha fazla olan seçimlerdir (Doğan ve Göker, 2011:46). Bu nedenle seçmenleri birden fazla bilgi kanalını kullanması bir ihtiyaç olarak değerlendirilebilir.

Ek tablo 2'de 10. soru ile katılımcıların eğitim durumu arasında çapraz ilişki kurulmuştur. Bu tabloya bakıldığında "aile büyüklerimin etkisinde kalırım" diyenlerin oranı okuryazar olmayanlar arasında \% $\quad 31,81$ iken, lisans mezunları arasında bu oran \% 7,84'dür. Böylece eğitim düzeyi yükselirken, başkasında etkilenme oranının düştüğü görülmektedir. Ancak medya ve sosyal medyanın etkisinde kalma konusunda tersi bir durum söz konusudur. "Medya ve sosyal medyadan etkilenirim" diyenlerin okuryazar olmayanlar arasında \% 22.72 iken, lisans mezunları arasında bu oran \% 38,25'e çıkmaktadır. Burada da eğitim düzeyi yükseldikçe, medyadan etkilenme oranının da arttığı sonucu ortaya çıkmaktadır.

Katılımcılara 11. soru olarak "yerel seçimlerde oy verme kararınız ne zaman netleşir?" sorusu yöneltilmiştir. Bu soruya verilen cevaplar tablo 12'de yer almaktadir.

Tablo 12. Katılımcıların Yerel Seçimlerde Oy verme Kararının Ne Zaman Netleştiği

\begin{tabular}{ccc}
\hline Seçenekler & Sayı & Yüzde \\
\hline Adaylar belirlendikten sonra & 90 & 23,7 \\
\hline Oy vereceğim parti her zaman bellidir & 153 & 40,3 \\
\hline Seçim kampanyalarını takip ettikten sonra & 76 & 20,0 \\
\hline Seçimden bir iki gün önce & 18 & 4,7 \\
\hline Sandık başında & 22 & 5,8 \\
\hline
\end{tabular}

Tablo 13. Katılımcıların Yerel Seçimlerde Oy Verirken Neyi Daha Çok Önemsedikleri

\begin{tabular}{cccc}
\hline Seçenekler & Sayı & 26 & Yüzde \\
\hline Parti lideri & 67 & 6,8 \\
\hline Parti & 55 & 17,6 \\
\hline Aday & 214 & 14,5 \\
\hline Hem aday hem parti & 15 & 36,3 \\
\hline Diğer & 3,9 \\
\hline Cevapsiz & 380 \\
\hline
\end{tabular}

12. soruya verilen cevaplar içerisinde yerel seçimlerde oy verirken katılımcıların \% 56,3'ü hem adayı hem de partiyi önemsediğini belirtmiştir. Bu sonuç daha önceki cevaplarla yaklaşık olarak uyumludur. Aynı şekilde 9. Soruya verilen cevaplarda belediye başkanı seçiminde adayın partisine öncelik verenlerin oranı \% 15,6 iken, burada adayın partisini önemseyenlerin oranı \% 17,6 çıkmıştır. Yine 9. soruda adayın kişiliğini dikkate alırım diyenlerin oranı \% 14,36 iken, burada aday benim için önemlidir diyenlerin

\begin{tabular}{ccc}
\hline Diğer & 18 & 4,7 \\
\hline Cevapsız & 3 & 0,8 \\
\hline Toplam & 380 & 100 \\
\hline
\end{tabular}

Tablo 12'de görüldüğü gibi, katılımcıların $\% \quad 40,3{ }^{\prime}{ }_{1}$ desteklediği siyasi partiye göre karar verdiği için, dolayısıyla kararının önceden oluştuğunu belirtmiştir. Bu soruya verilen cevaplar ile, 9. Soruya verilen cevaplar arasında bir farklılaşma oluşmuştur. Çünkü 9. Soruda belediye başkanı seçerken adayın mensup olduğu partiyi göz önünde bulundururum diyenlerin oranı $\% \quad 15,6$ çıkmıştır. Gerçi yerel seçimlerde belediye meclisi üyesi ile il genel meclisi üyelerinin de seçimi yapıldığından buradaki parti faktörünün daha çok belediye meclisi üyeleri ile il genel meclisi üyelerine yönelik olduğu değerlendirilebilir. Çünkü gözleme göre belediye meclis üyeleri ile il genel meclisi üyeleri kamuoyunda pek tanınmadığından, seçmen bu konudaki tercihini daha çok siyasi parti mensubiyeti bağlamında yapmaktadır.

Bu soruya verilen cevaplar içinde seçmenlerin \% 23,7'sinin adaylar belirlendikten sonra, \% 20'sinin ise seçim kampanyalarını takip ettikten sonra karar verdiğini beyan etmesi de oldukça önemlidir. Genel olarak bu durum siyasi partiler tarafinda da bilindiği için, mümkün olduğu kadar kamuoyunu etkileme kapasitesi yüksek olan bir aday belirleme ve seçim sürecinde etkili bir kampanya yürütme çabası içindedirler. Ancak adayların yaklaşık \% 6'sının sandık başında karar verdiğini söylemesi de ilginç bir durumdur. Bu son ana kadar kararsız bir seçmen kitlesinin var olduğu anlamına gelir.

Katılımcılara 12. soru olarak "yerel seçimlerde oy verirken sizin için hangisi daha önemlidir?” sorusu yöneltilmiştir. $\mathrm{Bu}$ soruya verilen cevaplar tablo 11 'de yer almaktadır. oranı \%14,5 çıkmıştır. Katılımcıların \% 6,8'i ise parti liderinin kendileri için önemli olduğunu belirtmiştir. Bu sonuçtan parti veya adaydan bağımsız olarak, parti liderinin de tercihte önemli bir faktör olduğu anlaşılmaktadır.

Ankette 13. Soru olarak katılımcılara "belediye başkanının seçim konuşmaları ve diğer seçim çalışmaları siyasi tercihinizi etkiler mi?" sorusu yöneltilmiştir. Bu soruya verilen cevaplar Tablo 14 'de yer almaktadır. 
Tablo 14. Belediye Başkanı Adayının Seçim Konuşmaları ve Diğer Seçim Çalışmalarının Katılımcıların Siyasi Tercihini Etkileyip Etkilemediği

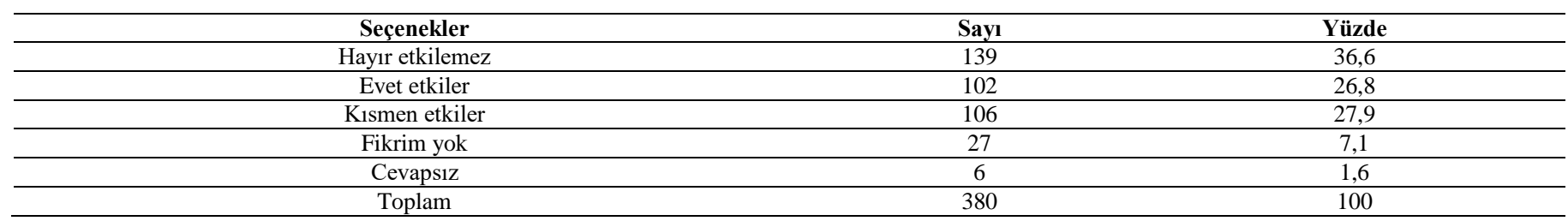

Katılımcıların \% 36,6'sı seçim çalışmaları ile seçim konuşmalarının kararında/tercihinde etkili olmadığını belirtmiştir. Bunun nedeni olarak parti bağlamında tercihin önceden belli olması gösterilebilir. Nitekim 11. soruda katılımcıların \% 40’1 desteklediği parti doğrultusunda tercihte bulunduğunu belirtmiştir. Ancak katılımcıların \% 54,7'sinin seçim çalışma ve konuşmalarından etkilendiğini belirtmesi de oldukça önemli bir orandır. Bu durum sadece siyasi parti kimliği ile yerel seçim kazanmanın oldukça zor olduğunu göstermektedir. Siyasi parti kimliği yanında, nitelikli bir aday ve iyi yürütülen seçim çalışmanın sonuç alıcı nitelikte olacağı görülmektedir.

Ankette 17. Soru olarak "İyi Çalışan / Kentin Sorunlarını Çözebilen Bir Belediye Başkanının Seçilmesini Ne Kadar Önemsersiniz?" sorusu katılımcılara yöneltilmiştir. Bu soruya verilen cevapların dağılımı Tablo 13'te verilmiştir.

Tablo 15. Katılımcıların İyi Çalışan/Kentin Sorunlarını Çözebilen Bir Belediye Başkanın Seçilmesini Ne Kadar Önemsediği

\begin{tabular}{ccc}
\hline Seçenekler & Sayı & Yüzde \\
\hline Çok önemserim & 264 & 69,5 \\
\hline Önemserim & 102 & 26,8 \\
\hline Önemsemem & 9 & 2,4 \\
\hline Cevapsiz & 5 & 1,3 \\
\hline Toplam & $\mathbf{3 8 0}$ & $\mathbf{1 0 0}$ \\
\hline
\end{tabular}

Tablo15'te açıkça görüldüğü gibi, seçmenlerin 96,3'ü iyi çalışan ve kentin sorunlarını çözebilen bir belediye başkanı istemektedir. Katılımcıların iyi çalışan/kentin sorunlarını çözebilen bir belediye başkanın seçilmesini ne kadar önemsediği sorusuna \% 69,5 ile çok önemserim ve \% 26,8 'inin ise önemserim cevabını vermesi katılımcıların, yerel seçimlerde tercih yaparken karar merkezlerine hizmeti koydukları ve hizmet odaklı karar verdikleri anlaşılmaktadir.

Katılımcılara 18. Soru olarak "sizce ideal bir belediye başkanı nasıl olmalı?" sorusu yöneltilmiş ve bu soruda katılımcılara birden fazla şıkkı işaretleme hakkı verilmiştir. $\mathrm{Bu}$ soruya verilen cevaplar Tablo 14'te belirtilmiştir.

Tablo 16. Katılımcıların İdeal Bir Belediye Başkanının Nasıl Olması Gerektiği Konusundaki Görüşleri

\begin{tabular}{ccc}
\hline Seçenekler & Sayı & Yüzde \\
\hline $\begin{array}{c}\text { Belediyecilik Konusunda Bilgi ve Beceriye } \\
\text { Sahip Olmalı }\end{array}$ & 101 & 16,64 \\
\hline $\begin{array}{c}\text { Liderlik Vasıflarına Sahip Olmalı } \\
\text { Topluma Örnek Olacak Bir Kişiliğe Sahip } \\
\text { Olmalı }\end{array}$ & 56 & 9,23 \\
\hline
\end{tabular}

\begin{tabular}{ccc}
\hline Azimli ve Çalışkan Olmalı & 79 & 13,01 \\
\hline Dürüst Olmalı & 82 & 13,51 \\
\hline Hepsi & 234 & 38,55 \\
\hline Diğer & 5 & 0,82 \\
\hline
\end{tabular}

Not: Bu soruda katılımcılara birden fazla seçeneği işaretleme hakk1 verilmiştir.

Tablo 14'e bakıldığında, seçmenin ideal belediye başkanını betimlemede oldukça başarılı olduğu görülmektedir. Katılımcıların \% 40'a yakını; belediyecilik konusunda bilgi ve beceriye sahip olma, liderlik vasıflarına sahip olma, topluma örnek olacak bir kişiliğe sahip olma, azimli ve çalışkan olma, dürüst olma vasıflarının bütününün belediye başkanında olması gerektiğini düşünmektedir. Bunun dışında katılımcılarca ön plana çıkarılan diğer bir husus belediye başkanının "belediyecilik konusunda bilgi ve beceriye sahip olma"sı gerektiği düşüncesidir. Böylece seçmenin alanla ilgili uzmanlık bilgisini önemsediği görülmektedir. Uzmanlık bilgisi dışında katılımcıların belediye başkanının kişiliği ile ilgili olan "azimli ve çalışkan olma" ile "dürüst olma" niteliklerini önemsedikleri anlaşılmaktadır.

Son soru olarak katılımcıların konu hakkındaki görüşleri ifade etmeye imkân sağlamak amaciyla "ifade etmek istediğiniz başka bir konu varsa lütfen kısaca belirtiniz?" biçiminde bir soru anket kâğıdında yer almıştır. Bu soru kapsamında ifade edilen başlıca görüşler şunlardır:

- Belediye gençler için uygun istihdam alanları yaratarak onların şiddette yönelmelerine engel olmal1,

- Belediye sokak hayvanlarını sokaktan toplayarak hayvan barınaklarına yerleştirmeli,

- Kadınların daha rahat bir şekilde sosyal hayata karışabilecekleri imkânlar oluşturulmalı ve sadece kadınların girip çıkabileceği yerler yapılmalı,

- Kaldırımların kahvehanelerden arındırılarak halkın rahatlıkla kullanabileceği bir hale getirilmeli,

- Kent planlaması yapılarak çarpık ve insan hayatını tehdit eden yapıların önüne geçilmeli,

- Halkında faydalanabileceği donanımlı, yeterli bir kütüphanenin inşa edilmesi,

- Şeffaf ve hesap verebilir belediyecilik ve siyaset anlayışının geliştirilmesi,

- Sik ve uzun süreli su kesintilerinin önüne geçilmesi, 
- Eski Hal civarının 1slah edilerek insanların kullanabileceği sosyal bir alana dönüştürülmesi ve Eski Hal için şehir dışında daha modern bir yer inşa edilmesi,

- Belediyenin sportif faaliyetlerle doğrudan ilgilenerek yetenekli çocukları keşfetmesi ve bu sayede çocukların kötü alışkanlıklara yönelmesinin engellenmesi.

Açık uçlu soru kapsamında ifade edilen görüş ve önerilerin vatandaşların yaşadıkları sorunlara çözüm önerisi niteliğinde olduğu görülmektedir. Bunun yanında var olan bazı hizmetleri daha iyi sunulmasına yönelik öneriler de vardir.

\section{Sonuç}

Yerel yönetimlerin idare yapımız içinde yer almaları 150 yılı aşmış durumdadır. $\mathrm{Bu}$ uzun süre içinde başta belediyeler olmak üzere, yerel yönetimlerin vatandaşlar tarafından benimsendiği görülmektedir. Aynı zamanda yerel yönetimler açısından seçim ve temsil olgusu vazgeçilmez nitelikte olduğundan, yerel yönetimlerin ülkedeki demokratik rejimi geliştirdiği ve güçlendirdiği kabul edilmektedir. Bunun yanında yerel yönetimlerin sunduğu kentsel hizmetler, kent sakinleri açısından vazgeçilmez niteliktedir.

Genel olarak değerlendirildiğinde seçmenlerin, yerel yönetimlerin özellikle belediyelerin öneminin farkında olduğu söylenebilir. Dolayısıyla yerel seçimler ve bu yerel seçimlerin sonuçları da seçmenler tarafindan önemsenmektedir. $\mathrm{Bu}$ nedenle yerel seçimlerde seçmen tercihi genellikle iç ve dış faktörlerin etkisiyle bilinçli davranışlar neticesinde oluşmaktadır. Seçmen davranışına/tercihine etki eden iç ve dış faktörlerin ne olduğunun bilinmesi amacıyla teorik analizler yanında alanda bilimsel çalışmalar da yürütülmektedir. Burada önemli sonuçları ortaya konulan alan araştırması 2015 yılında Muş Belediyesi sınırları içinde yaşayan seçmenlere yönelik olarak yapılmıştır. Bu alan araştırmasının Muş Belediyesi sınırları içinde yaşayan seçmenler açısından bazı önemli bulguları şunlardır:

- Belli bir siyasi partiye bağlılık duyan ve seçim zamanında buna dayalı olarak karar veren ve dolayısıyla diğer faktörleri göz ardı eden bir seçmen grubunun varlığından söz edilebilir. Bu çalışmada 11. soruya verilen cevaplar dikkate alındığında bu grubun toplam seçmen sayısının \% 40'ın üstünde olduğu görülmektedir. Dolayısıyla bu seçmenler için yerel hizmetin kalitesi veya bu hizmetlerin iyi bir biçimde sunulması ikincil düzeyde kalmaktadır. Bu grubun yaklaşımı teorideki "sosyo-psikolojk yaklaşımı" doğrular niteliktedir.

- Seçmenler açısından adayların kişilikleri ile kişisel özellikleri önemlidir ve bu olgular oy verme davranışını etkilemektedir.

- Seçmenlerin bazılarının içsel faktörlerin etkisiyle (örneğin adayın dindar olup almadığına bakma) bazısının da sosyal ilişkilerin (aşiret vb.) etkisiyle tercihlerini oluşturduğu görülmektedir. $\mathrm{Bu}$ kategorideki seçmenler için de yerel hizmet kalitesi veya bu hizmetlerin iyi bir biçimde sunulmasının ikincil düzeyde kaldığı söylenebilir. Bu kesimin yaklaşımı ise, teorideki "sosyolojik yaklaşım" kapsamında değerlendirilebilir.

- Anketin genel sonuçlarına bakıldığında, yerel yönetim birimlerinin iyi yönetilmesini dolayısıyla kaliteli ve nitelikli yerel hizmet sunulmasını isteyen ve bunu önceleyen bir seçmen grubunun da var olduğu görülmektedir.

- Yine anketin genel sonuçları göz önünde bulundurulduğunda teorideki "sosyolojik yaklaşım", sosyo-psikolojik yaklaşım ve "ekonomik yaklaşım" kapsamı içinde değerlendirilebilecek üç farklı seçmen grubundan söz edilebilir.

Küreselleşme ve teknolojik gelişmelerle birlikte dünyanın tabir edildiği şekilde artık "Küresel Bir Köy" haline gelmesi sonucu dünyanın herhangi bir yerinde cereyan eden bir olayın artık diğer yerlerde duyulması sıradan bir hal almıştır. Buna bağlı olarak bütün dünyada yerel yönetim ya da daha doğru bir ifade ile yerel demokrasi bu kadar önemli bir boyuta ulaşmışken ülkemizi bundan geri kalması beklenemez, araştırmamızda da ortaya konulduğu üzere seçmenin her geçen gün bilinçlenmesi ile birlikte yerel yönetimler ve Muş özelinde yerel demokrasi gittikçe daha fazla güçlenmekte ve gelişmektedir. $\mathrm{Bu}$ temelden hareketle çalışmanın tamamı göz önünde bulundurulur ise; seçmen belediye başkanı seçimi sürecinde aile, arkadaş grubu, kanaat önderleri gibi yakın çevresinden etkilenmekte, oy tercihini belirlerken ilk önce adayın kişiliğinden daha sonra adayın partisinden etkilenmektedir. Seçmenlerin eğitim durumuna bağlı olarak yerel seçimlerde oy kullanırken etkilendikleri faktörler değişmekte ve meslek grupları çözülmesi için sorun olarak kendi şartlarını kısıtlayan meseleleri görmektedir. Siyasetin temel amacı seçmenin sorunlarını dinlemek ve bu yol ile tespit edilen meselelere çözüm üretmektir. Çalışmamızın bu anlamda temel gereklilik olan veri sağlama noktasında alana katkı sunması umut edilmektedir. 



\section{Ek Tablolar:}

Ek Tablo 1. Katılımcıların Öğrenim Durumu İle Belediye Başkanını Seçerken Dikkat Ettikleri Özelliklere İlişkin Çapraz Tablo

\begin{tabular}{|c|c|c|c|c|c|c|c|c|c|c|c|c|c|c|}
\hline \multirow{2}{*}{$\begin{array}{l}\begin{array}{l}\text { Öğrenim } \\
\text { Durumu }\end{array} \\
\text { Görüşler }\end{array}$} & \multicolumn{2}{|c|}{$\begin{array}{c}\text { Okuryazar } \\
\text { Değil }\end{array}$} & \multicolumn{2}{|c|}{ Okuryazar } & \multicolumn{2}{|c|}{$\begin{array}{l}\text { İlkokul } \\
\text { Mezunu }\end{array}$} & \multicolumn{2}{|c|}{$\begin{array}{l}\text { Ortaokul } \\
\text { Mezunu }\end{array}$} & \multicolumn{2}{|c|}{ Lise Mezunu } & \multicolumn{2}{|c|}{$\begin{array}{c}\text { Ön Lisans } \\
\text { Mezunu }\end{array}$} & \multicolumn{2}{|c|}{$\begin{array}{c}\text { Lisans } \\
\text { Mezunu }\end{array}$} \\
\hline & Sayı & $\%$ & Sayı & $\%$ & Sayı & $\%$ & Sayı & $\%$ & Sayı & $\%$ & Sayı & $\%$ & Sayı & $\%$ \\
\hline $\begin{array}{l}\text { Adayın Kişiliğini } \\
\text { Dikkate Alırım }\end{array}$ & 10 & 45,45 & 8 & 30,75 & 5 & 13,51 & 7 & 26,92 & 29 & 38,15 & 18 & 45 & 65 & 42,48 \\
\hline $\begin{array}{l}\text { Adayın Dindar } \\
\text { Olup Olmadığını } \\
\text { Dikkate Alırım } \\
\end{array}$ & 7 & 31,81 & 6 & 23,07 & 5 & 13,51 & 7 & 26,92 & 17 & 22,36 & 11 & 27,5 & 27 & 17,64 \\
\hline $\begin{array}{c}\text { Adayın Etnik } \\
\text { Kökenini Dikkate } \\
\text { Alırım } \\
\end{array}$ & 6 & 27,27 & 3 & 11,53 & 5 & 13,51 & 4 & 15,38 & 6 & 7,90 & 3 & 7,5 & 7 & 4,57 \\
\hline $\begin{array}{c}\text { Adayın Siyasi } \\
\text { Deneyiminin Olup } \\
\text { olmamasını } \\
\text { Dikkate Alırım } \\
\end{array}$ & 5 & 22,72 & 8 & 30,76 & 6 & 16,21 & 6 & 23,07 & 16 & 21,05 & 14 & 35 & 40 & 26,14 \\
\hline $\begin{array}{c}\text { Adayın Eğitim } \\
\text { Durumunu Dikkate } \\
\text { Alırım }\end{array}$ & 2 & 9,09 & 6 & 23,07 & 4 & 0,81 & 4 & 15,38 & 23 & 30,26 & 16 & 40 & 57 & 37,25 \\
\hline $\begin{array}{l}\text { Adayın Fiziksel } \\
\text { Görünümünü } \\
\text { Dikkate Alırım }\end{array}$ & 0 & 0 & 0 & 0 & 0 & 0 & 1 & 3,84 & 2 & 2,63 & 1 & 2,5 & 4 & 2,6 \\
\hline $\begin{array}{c}\text { Adayın Hangi } \\
\text { Partiye Mensup } \\
\text { Olduğunu Dikkate } \\
\text { Alırım } \\
\end{array}$ & 8 & 36,36 & 6 & 23,07 & 14 & 37,83 & 11 & 42,30 & 33 & 43,42 & 15 & 37,5 & 62 & 40,52 \\
\hline $\begin{array}{c}\text { Adayın Hangi } \\
\text { Aşirete Mensup } \\
\text { Olduğunu Dikkate } \\
\text { Alırım } \\
\end{array}$ & 10 & 45,45 & 2 & 7,69 & 8 & 21,62 & 4 & 15,38 & 6 & 7,89 & 1 & 2,5 & 7 & 4,57 \\
\hline $\begin{array}{l}\text { Adayın Belediye } \\
\text { Yönetimi } \\
\text { Konusundaki Bilgi } \\
\text { ve Tecrübesini } \\
\text { Dikkate Alırım } \\
\end{array}$ & 8 & 36,36 & 12 & 45,15 & 15 & 40,54 & 11 & 42,30 & 35 & 43,05 & 22 & 55 & 86 & 56,20 \\
\hline $\begin{array}{c}\text { Adayın Yerel } \\
\text { Ekonomiye Olumlu } \\
\text { Katkı Yapıp } \\
\text { Yapmayacağını } \\
\text { Dikkate Alırım }\end{array}$ & 4 & 18,18 & 3 & 11,53 & 13 & 35,13 & 9 & 34,61 & 28 & 36,84 & 16 & 40 & 62 & 40,52 \\
\hline
\end{tabular}

Geçmişte olduğu gibi günümüzde de din olgusu siyasi tercihin belirlenmesinde önemli bir rol oynamaktadır. Dini hassasiyet genellikle eğitim seviyesi düşük kesimlerde daha yoğun olmaktadır. Bu tamamen kendini güvende hissetmek için daha dindar olana yönelme ihtiyacından kaynaklanabileceği düşüncesindeyiz. Nihayetinde anketimizde de adayın dindar olmasına \% 31,81 oranla en fazla okuryazar olmayanlar önem vermiştir. Aynı kesim \% 27,27 oranla adayın etnik kökenine de önem verdiklerini belirtmişlerdir. Oysa adayın eğitim durumu ile ilgili soruda en fazla oran \% 37,25 ile lisans mezunu olanlarda ortaya çıkmıştır.
Okuryazar olmayan kesim \% 45,45 ile adayın aşiretine önem verdiklerini, lisans mezunları ise \% 56,20 oranı ile adayın belediye yönetimi konusundaki bilgi ve tecrübesine önem verdiklerini dile getirmişlerdir. Aynı lisans mezunları adayın yerel ekonomiye katkı sunması gerektiğini, \%40,52 ile dile getirmiştir. Buradan eğitim seviyesine bağlı olarak kesimlerin beklentilerinin değiştiğini görüyoruz. Eğitim seviyesi düştükçe daha geleneksel ve miadını doldurmak üzere olan faktörler etkili olurken, eğitim seviyesinin gelişmesine bağlı olarak daha çok hizmete odaklanılmakta ve daha rasyonel taleplerde bulunulmaktadır. 
Ek Tablo 2. Katılımcıların Öğrenim Durumu İle Yerel Seçimlerde Oy Kullanırken Etkilendikleri Faktörlere İlişkin Çapraz Tablo

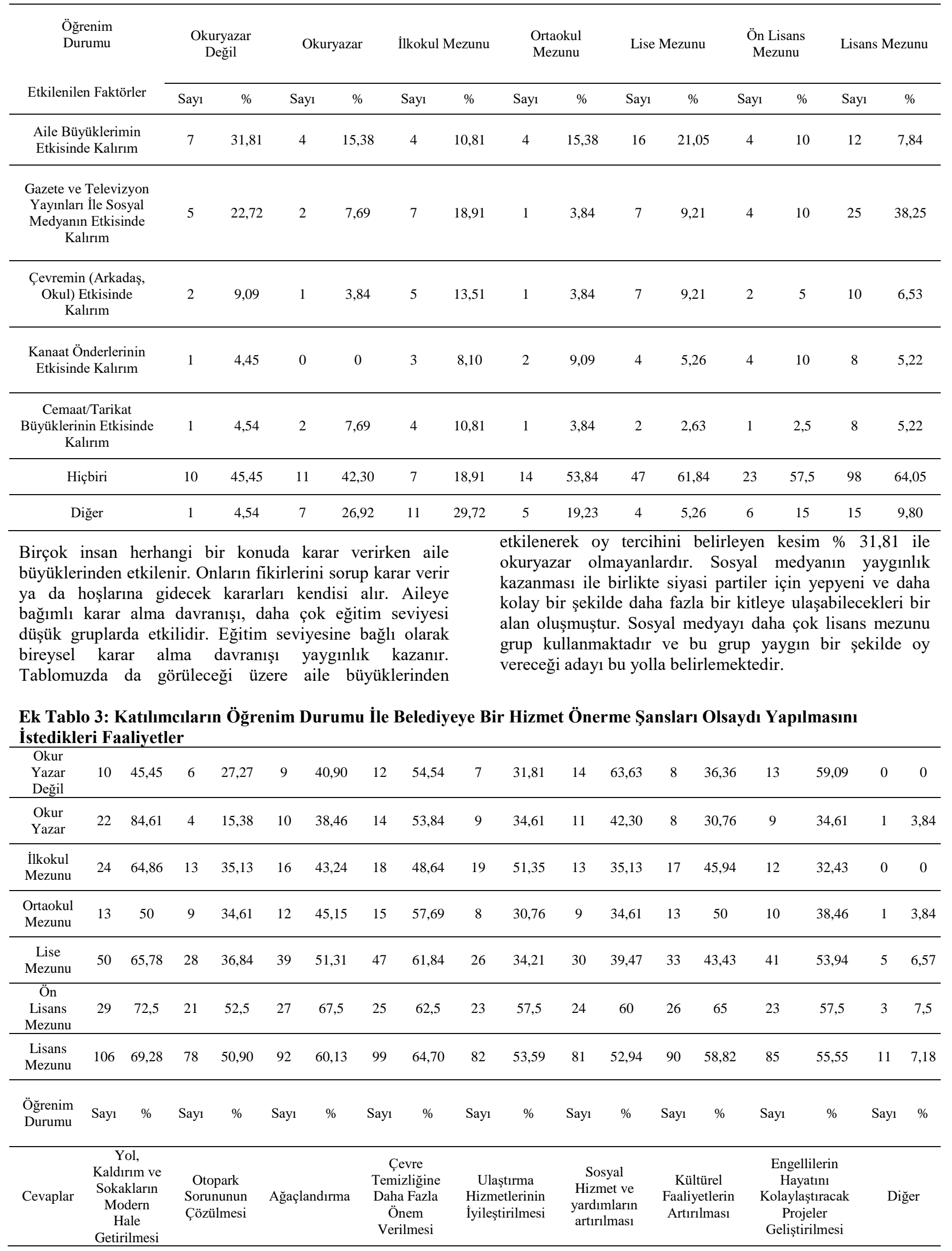


Birçok insan herhangi bir konuda karar verirken aile büyüklerinden etkilenir. Onların fikirlerini sorup karar verir ya da hoşlarına gidecek kararları kendisi alır. Aileye bağımlı karar alma davranışı, daha çok eğitim seviyesi düşük gruplarda etkilidir. Eğitim seviyesine bağlı olarak bireysel karar alma davranışı yaygınlık kazanır. Tablomuzda da görüleceği üzere aile büyüklerinden etkilenerek oy tercihini belirleyen kesim \% 31,81 ile okuryazar olmayanlardır. Sosyal medyanın yaygınlık kazanması ile birlikte siyasi partiler için yepyeni ve daha kolay bir şekilde daha fazla bir kitleye ulaşabilecekleri bir alan oluşmuştur. Sosyal medyayı daha çok lisans mezunu grup kullanmaktadır ve bu grup yaygın bir şekilde oy vereceği adayı bu yolla belirlemektedir.

Ek Tablo 4: Katılımcıların Meslekleri İle

Belediyeye Bir Hizmet Önerme Şansları Olsaydı Ne Yapılmasını İstedikleri

\begin{tabular}{|c|c|c|c|c|c|c|c|c|c|c|c|c|c|c|c|c|c|c|}
\hline Esnaf & 31 & 72,09 & 15 & 34,88 & 18 & 41,86 & 23 & 53,48 & 19 & 44,18 & 19 & 44,18 & 19 & 44,18 & 21 & 48,83 & 2 & 4,65 \\
\hline $\begin{array}{l}\text { Serbest } \\
\text { meslek }\end{array}$ & 14 & 56 & 9 & 36 & 11 & 44 & 14 & 56 & 12 & 48 & 12 & 46,15 & 15 & 60 & 13 & 52 & 1 & 4 \\
\hline $\begin{array}{c}\text { Kamu } \\
\text { görevlisi/ } \\
\text { memur }\end{array}$ & 107 & 69,03 & 79 & 50,96 & 87 & 56,12 & 94 & 60,64 & 76 & 49,03 & 70 & 45,16 & 77 & 49,67 & 82 & 52,90 & 13 & 8,38 \\
\hline Çiftçi & 2 & 50 & 0 & 0 & 1 & 25 & 1 & 25 & 2 & 50 & 1 & 25 & 1 & 25 & 0 & 0 & 0 & 0 \\
\hline Emekli & 7 & 46,66 & 5 & 33,33 & 4 & 26,66 & 5 & 33,33 & 4 & 26,66 & 6 & 40 & 4 & 26,66 & 2 & 13,33 & 0 & 0 \\
\hline $\begin{array}{c}\text { Ev } \\
\text { Hanımı }\end{array}$ & 34 & 61,81 & 17 & 30,90 & 33 & 60 & 39 & 70,90 & 19 & 34,54 & 33 & 60 & 28 & 50,90 & 32 & 58,18 & 1 & 1,81 \\
\hline İşsiz & 15 & 65,21 & 6 & 26,08 & 8 & 34,78 & 8 & 34,78 & 6 & 26,08 & 6 & 26,08 & 11 & 47,82 & 9 & 39 & 0 & 0 \\
\hline Öğrenci & 23 & 85,18 & 12 & 44,44 & 20 & 74,07 & 21 & 77,77 & 16 & 59,25 & 17 & 62,96 & 20 & 74,07 & 17 & 13 & 1 & 3,70 \\
\hline Diğer & 21 & 63,63 & 16 & 48,48 & 23 & 69,69 & 25 & 75,75 & 20 & 60,60 & 18 & 54,54 & 20 & 60,60 & 17 & 51,51 & 3 & 9,09 \\
\hline $\begin{array}{l}\text { Öğrenim } \\
\text { Durumu }\end{array}$ & Sayı & $\%$ & Sayı & $\%$ & Sayı & $\%$ & Sayı & $\%$ & Sayı & $\%$ & Sayı & $\%$ & Sayı & $\%$ & Sayı & $\%$ & Sayı & $\%$ \\
\hline Cevaplar & \multicolumn{2}{|c|}{$\begin{array}{c}\text { Yol, } \\
\text { Kaldırım ve } \\
\text { Sokakların } \\
\text { Modern } \\
\text { Hale } \\
\text { Getirilmesi } \\
\end{array}$} & \multicolumn{2}{|c|}{$\begin{array}{c}\text { Otopark } \\
\text { Sorununun } \\
\text { Çözülmesi }\end{array}$} & \multicolumn{2}{|c|}{ Ağaçlandırma } & \multicolumn{2}{|c|}{$\begin{array}{c}\text { Çevre } \\
\text { Temizliğine } \\
\text { Daha Fazla } \\
\text { Önem } \\
\text { Verilmesi }\end{array}$} & \multicolumn{2}{|c|}{$\begin{array}{c}\text { Ulaştırma } \\
\text { Hizmetlerinin } \\
\text { İyileştirilmesi }\end{array}$} & \multicolumn{2}{|c|}{$\begin{array}{c}\text { Sosyal } \\
\text { Hizmet ve } \\
\text { yardımların } \\
\text { artırılması }\end{array}$} & \multicolumn{2}{|c|}{$\begin{array}{c}\text { Kültürel } \\
\text { Faaliyetlerin } \\
\text { Artırılması }\end{array}$} & \multicolumn{2}{|c|}{$\begin{array}{c}\text { Engellilerin } \\
\text { Hayatını } \\
\text { Kolaylaştıracak } \\
\text { Projeler } \\
\text { Geliştirilmesi } \\
\text { Diğer } \\
\end{array}$} & \multicolumn{2}{|c|}{ Diğer } \\
\hline
\end{tabular}

Bir kentin görsel güzellikleri mutlaka her kesim için çok önemlidir. Tablomuzdan da anlaşılacağı üzere bu konu herkesin dikkatini çekmiş ve her kesim bu konuya önem vererek ortalama \% 50 civarı yol, kaldırım ve sokakların modern hale getirilmesini savunmuştur. Tabi daha bilinçli ve yol kaldırımı kendine dert eden kesim olarak öğrenciler bu konuya \% 85,18 oranda destek vermiştir. Yine öğrenci grubu \% 74,07 gibi yüksek bir oran ile kültürel faaliyetlerin geliştirilmesini ve \% 74,07 ile ağaçlandırmanın yapılmasını isteyerek hem kendisine sosyalleşme alanları yaratılmasını talep etmiştir hem de yeşil bir kentte yaşama isteğini dillendirmiştir. Öğrenci grubunun bir diğer dikkat çeken talebi \% 59,25 ile ulaşım sorunu olmuştur ki bu da kanımızca; üniversite öğrencilerinin okullarına gidip gelmede yaşadıkları sorunun bir yansıması olmuștur. Otopark sorununu çözülmesi gerektiğini en fazla savunan kesim \% 50,96 ile kamu görevlileri olmuştur. Bunun temel nedeni; kamu görevlilerinin trafik düzeni konusunda daha duyarlı olmalarından kaynaklanıyor olmalı kanımızca. 
Ek Tablo 5: Katılımcıların Öğrenim Durumu ile

İdeal Bir Belediye Başkanında Olmasını İstedikleri Özellikler.

\begin{tabular}{|c|c|c|c|c|c|c|c|c|c|c|c|c|c|c|}
\hline $\begin{array}{c}\text { Okuryazar } \\
\text { değil }\end{array}$ & 4 & 18,18 & 0 & 0 & 2 & 9,09 & 2 & 9,09 & 2 & 9,09 & 16 & 72,72 & 0 & 0 \\
\hline $\begin{array}{l}\text { Okur } \\
\text { Yazar }\end{array}$ & 6 & 23,08 & 3 & 11,54 & 3 & 11,54 & 5 & 19,23 & 5 & 19,23 & 17 & 65,38 & 0 & 0 \\
\hline $\begin{array}{l}\text { İlkokul } \\
\text { mezunu }\end{array}$ & 5 & 13,51 & 4 & 10,81 & 4 & 10,81 & 4 & 10,81 & 6 & 16,22 & 27 & 72,97 & 0 & 0 \\
\hline $\begin{array}{c}\text { Ortaokul } \\
\text { mezunu }\end{array}$ & 8 & 30,77 & 3 & 11,54 & 6 & 23,08 & 4 & 15,38 & 6 & 23,08 & 16 & 61,54 & 0 & 0 \\
\hline $\begin{array}{c}\text { Lise } \\
\text { mezunu }\end{array}$ & 21 & 27,63 & 16 & 21,05 & 14 & 18,42 & 19 & 25 & 18 & 23,68 & 42 & 55,26 & 2 & 2,63 \\
\hline $\begin{array}{c}\text { Ön lisans } \\
\text { mezunu }\end{array}$ & 11 & 26,19 & 8 & 20 & 5 & 12,5 & 8 & 20 & 11 & 26,19 & 25 & 62,5 & 1 & 2,5 \\
\hline $\begin{array}{l}\text { Lisans } \\
\text { mezunu }\end{array}$ & 46 & 30,06 & 22 & 14,38 & 16 & 10,46 & 37 & 24,18 & 34 & 22,22 & 91 & 59,48 & 2 & 1,31 \\
\hline $\begin{array}{l}\text { Öğrenim } \\
\text { Durumu }\end{array}$ & Say1 & $\%$ & Say1 & $\%$ & Say1 & $\%$ & Say1 & $\%$ & Sayı & $\%$ & Say1 & $\%$ & Say1 & $\%$ \\
\hline Cevaplar & \multicolumn{2}{|c|}{$\begin{array}{l}\text { Belediyecilik } \\
\text { Konusunda } \\
\text { Bilgi ve } \\
\text { Beceriye } \\
\text { Sahip Olmalı }\end{array}$} & $\begin{array}{r}\text { Lid } \\
\text { Vas1 } \\
\text { Sahip }\end{array}$ & $\begin{array}{l}\text { lik } \\
\text { arına } \\
\text { lmalı }\end{array}$ & \multicolumn{2}{|l|}{ Topluma } & \multicolumn{2}{|c|}{$\begin{array}{c}\text { Azimli ve } \\
\text { Çalışkan } \\
\text { Olmalı }\end{array}$} & \multicolumn{2}{|c|}{ Dürüst Olmalı } & \multicolumn{2}{|c|}{ Hepsi } & \multicolumn{2}{|c|}{ Diğer } \\
\hline
\end{tabular}

Belediye başkanı günümüzde yerel yönetim silsilesi içinde en önemli noktayı temsil etmektedir. Halkın çoğunlukla yakından tanıyarak ve buna bağlı olarak güvenerek seçtiği belediye başkanından doğal olarak beklentileri oldukça yüksek olmaktadır. İyi bir belediye başkanı; bir kentin çehresini değiştirerek insanlara sağlıklı bir ortamda yaşama imkânı sağlayabileceği gibi, bir kentin ekonomik, sosyal ve siyasi atmosferini de değiştirerek kent sakinlerine daha iyi şartlar sunabilmelidir. Nitekim daha bilinçli olduğunu kabul ettiğimiz lisans mezunu anket katılımcılarımızın \% 24,18' i belediye başkanının, azimli ve çalışkan olması gerektiğini savunmaktadir.

\section{Kaynakça}

Akgün, Birol (2002), Türkiye'de Seçmen Davranışı, Partiler Sistemi ve Siyasal Güven, Nobel Yayınları, Ankara.

Alkan, Türker (1989), Siyasal Bilinç ve Toplumsal Değişim, Gündoğdu Yayınları, Ankara.

Altıntaş, Cenkhan (2010), '’Seçmen Tipolojisi', Yüksek Lisans Tezi, Akdeniz Üniversitesi Sosyal Bilimler Enstitüsü, Antalya.

Bal, Hüseyin; Bakan, Selahaddin ve Koç,Yunus(2014), 'Sosyo-Politik Parametreler Açısından Van'daki Siyasal Temsil Anlayışı: Il Merkezi Üzerine Bir Araştırma', İletişim ve Diplomasi Dergisi, Temmuz(3), ss.128-152

BaykaL, Deniz (1970), Siyasal Katılma, Bir Davranış İncelenmesi, Sevinç Matbaası, Ankara.
Coşkun, Bayram ve Uzun, Turgay (1999), Türkiye'de Yerel Yönetimlerin Gelişimi, Niteliği ve Muğla İli Yerel Yönetimlerinin Uygulamada Karşılaştıkları Sorunlar, Muğla Üniversitesi Yayını, Muğla.

Çalışır, Vahit (2017), “Kırda Siyasal Davranış: Çukurova Örneği ’ , OPUS - Uluslararası Toplum Araştırmaları Dergisi, S.7(12), ss.145-156.

Çaha, Ömer (2008), Türkiye'de Seçmen Davranışı ve Siyasi Partiler, Orion Kitabevi, Ankara.

Çetin, Mehmet Şirin (2016), "Seçmen Davranışı ve Yerel Seçimler:Yerel Seçimlerde Muş Merkez Ilçedeki Seçmenlerin Oy Kullanma Davranışının Incelenmesi", Yüksek Lisans Tezi, Muş Alparslan Üniversitesi Sosyal Bilimler Enstitüsü, Muş.

Çukurçayır, Akif (2006), Siyasal Katılma ve Yerel Demokrasi, Çizgi Kitabevi, Konya.

Daver, Bülent (1993), Siyaset Bilimine Giriş, Siyasal Kitabevi, Ankara.

Doğan, Adem ve GÖKER, Göksel (2011), “Yerel Seçimlerde Seçmenlerin Siyasal Bilgi Düzeyi:Elazı̆̆ Seçmeni Örneği", e-Journal of New World Sciences Academy 2011, S.6(1), ss.42-59.

Doğan, Adem ve GÖKER, Göksel (2013), Siyasal İletişim Araştırmaları, Nobel Yayınları, Ankara..

Eroğlu, Feyzullah (2017), Davranış Bilimleri, Beta Yayınları, İstanbul, 15. Bask1.

Eryılmaz, Bilal (2013), Kamu Yönetimi, Umuttepe Yayınları, Kocaeli. 
Fedai, Cemal (2014), Siyaset Bilimi, Kadim Yayınları, Ankara.

Gülmen, Yüksel (1979), Türk Seçmen Davranışı, İstanbul Üniversitesi İletişim Fakültesi Yayınları, İstanbul.

Kalaycıŏlu, Ersin (2014), “Türkiye'de Seçmen Davranışı, Şimdi Neler Olacak', Toplumsal Düşünce Enstitüsü Dergisi, S.??, ss.01-12.

Kışlalı, Ahmet Taner (1987), Siyaset Bilimi, İmge Yayınevi, Ankara.

Koç, Yunus (2019), 'Türk Demokrasi Sürecinde Muş'ta Referandum ve Yerel Seçimler(1980-2019): Etkiler ve Sonuçlar' Bingöl Üniversitesi Sosyal Bilimler Enstitüsü Dergisi, Y1l: 9, Cilt: 9, Sayı: 18, ss.11131144.
Öğün, Süleyman Seyfi (2004), Türk Politik Kültürü, Alfa Aktüel Yayınları, Bursa.

Öztekin, Ali (2010), Siyaset Bilimine Giriş, Siyasal Kitabevi, Ankara.

Sencer, Muzaffer (1989), Toplum Bilimlerinde Yöntem, Beta Yayınları, İstanbul, 3. Baskı.

Tokgöz, Oya (2008), Siyasal İletişimi Anlamak, İmge Kitabevi, Ankara.

Torlak, Sülün Evinç ve POLAT, Ferihan (2006), “Denizli Örneği Çerçevesinde Kentlileşme Sürecinde Seçmen Davranışı Değişimi”, Mülkiye Dergisi, S.30(253), ss.149-166.

Tutar, Hasan, http://www.canaktan.org/yonetim/kurumsaldavranis/boyutlar.htm, (Erişim Tarihi: 07.08.2018) 